\title{
AVOIDING MURPHY'S LAW ON DETECTING METEORS
}

\author{
A. Castellón ${ }^{1,3}$ and A. J. Castro-Tirado ${ }^{2,3,4}$
}

\begin{abstract}
It is known that when a meteoroid has been imaged by two or more stations, its atmospheric trajectory can be inferred. In addition to this, if the velocity of the meteor has been measured, then the magnitude, the photometric mass and its orbital elements can be computed. Hence, meteor detection networks have a large number of stations. Unfortunately, weak meteors are only imaged by the nearest station, since the brightness decreases with the square of the distance. On the other hand, Murphy's law can act in the event of brilliant meteors and fireballs: "In a station it was cloudy. In another, the fireball was hidden under the horizon. A third was out of order due to an electrical power failure, and the other was under maintenance, etcetera." Do not panic. In this work we present some methods to obtain information from a meteor seen from a single station, if it has been possible to associate it with a meteor shower. In this work, CCD images gathered by the robotized networks of the Sociedad Malagueña de Astronomía (Aznar 2016) and the BOOTES-1 and -2 observatories have been used (Castro-Tirado et al. 2008).
\end{abstract}

\section{RESUMEN}

Es conocido que cuando un meteoroide ha sido captado por dos o más estaciones, su trayectoria atmosférica puede ser inferida. Además, si la velocidad del meteoroide ha sido medida, entonces su magnitud, masa fotométrica y elementos orbitales pueden ser calculados. De ahí que las redes de detección de meteoros consten de un gran número de estaciones. Por desgracia, los meteoros débiles son solo detectados por la estación más cercana, ya que su brillo decrece con el cuadrado de la distancia. Por otro lado, la Ley de Murphy puede actuar incluso en los casos de meteoros brillantes y bolas de fuego: "En una estación estuvo nublado. En otra la bola de fuego se ocultó bajo el horizonte. Una tercera se encontraba fuera de servicio debido a un fallo en el suministro eléctrico o por labores de mantenimiento, etcétera." Que no cunda el pánico. En este artículo presentamos algunos métodos para obtener información de un meteoroide visto desde una sola estación, siempre que haya sido posible asociarlo a una lluvia de estrellas. Las imágenes utilizadas han sido capturadas por la redes robotizadas de la Sociedad Malagueña de Astronomía (Aznar 2016) y los observatorios BOOTES-1 y 2 (Castro-Tirado et al. 2008).

Key Words: meteorites, meteors, meteoroids

\section{A PERSEID DETECTED BY TWO STATIONS}

To test the method described in later sections we used as an example a Perseid detected on August 13, 2017 by two all-sky cameras (one at SMA/OAT (Aznar 2016) and another one at the BOOTES-2 station (Castro-Tirado et al. 2008)) and a video camera (also at SMA/OAT) (see Figures 1 and 2).

From the observations of the event it is posible to calculate its atmospheric trajectory of the meteoroid, its speed and, of these, its magnitude and

\footnotetext{
${ }^{1}$ Departamento de Álgebra, Geometría y Topología, Facultad de Ciencias, Universidad de Málaga, Campus de Teatinos S/N, 29071 Málaga, Spain (apncs@uma.es).

${ }^{2}$ Instituto de Astrofísica de Andalucía (IAA-CSIC), P.O. Box 03004, 18080 Granada, Spain (ajct@iaa.es)

${ }^{3}$ Sociedad Malagueña de Astronomía, C/ República Argentina, 9, 29016 Málaga, Spain.

${ }^{4}$ Departamento de Ingeniería de Sistemas y Automática (unidad asociada a CSIC), Escuela Superior de Ingeniería Industrial, Campus de Teatinos S/N, 29071 Málaga, Spain.
}

photometric mass. The methods used for this are well known and can be consulted, for instance, in Ceplecha (1987), Dubyago (1961), and Borovička et al. (1995). The results are summarized in the Table 1 .

\section{ONLY SINGLE STATION AND KNOWN TIME}

A meteoroid has been seen from station S. The starting and ending points $(B$ and $F$ ) projected onto the celestial sphere determine a maximum circunference (Figure 3). If the radiant of an active meteor shower is close to this circumference, it is logical to suspect that the meteoroid is associated with such shower. Let $R^{\prime}$ be the closest point to the radiant $R$. The distance between $S$ and the vector $\overrightarrow{B F}$ is unknown. But if we have time tagged the duration $t$ of the meteor, the module of that vector should be $m=v t$, where $v$ is the typical speed of the associ- 


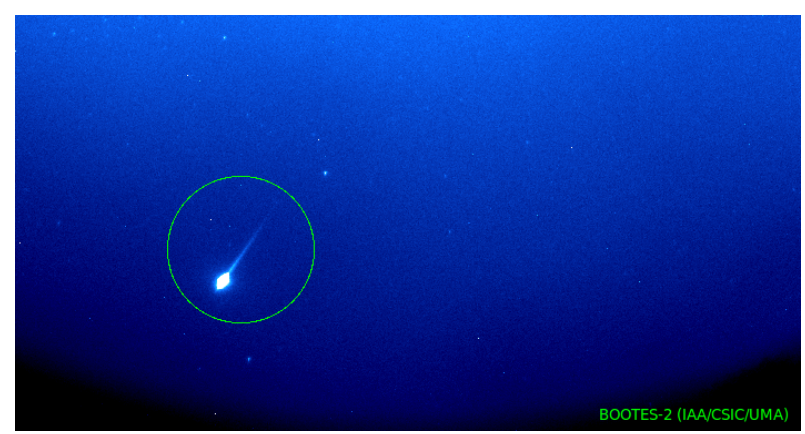

Fig. 1. Perseid on August 13 from BOOTES-2.

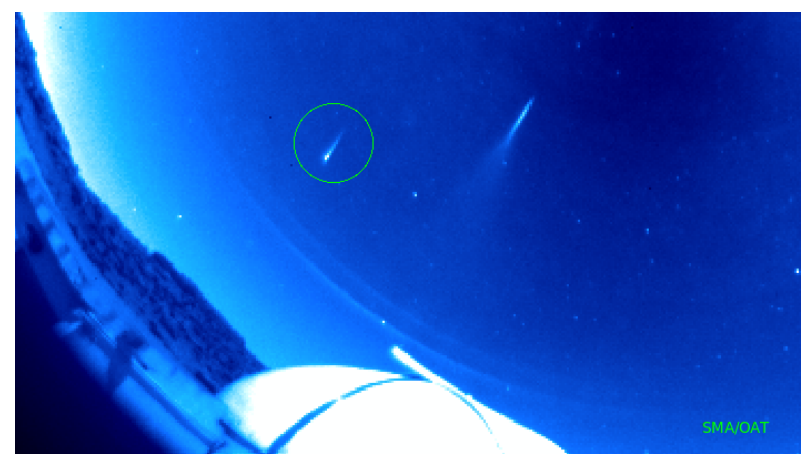

Fig. 2. Perseid on August 13 from OAT.

ated shower. Therefore, it is posible to compute a vector of module $m$, with origin in the line $\overline{S B^{\prime}}$ and end in the line $\overline{S F^{\prime}}$, whose direction is the opposite of the apparent radiant $R^{\prime}$.

Indeed. The coordinates of the vector $\overrightarrow{B F}$ are

$$
-(m \cos (\delta) \cos (\alpha), m \cos (\delta) \sin (\alpha), m \sin (\delta)),
$$

where $(\alpha, \delta)$ are the ecuatorial coordinates of $R^{\prime}$. The vector $\overrightarrow{S B}$ is obtained as a linear combination $\overrightarrow{S B}=\overrightarrow{O S}+\lambda_{b} v_{b}$, where $\lambda_{b}$ is the distance between the station $S$ and $B, v_{b}$ is an unitary vector $\left(\cos \left(\delta_{b}\right) \cos \left(\alpha_{b}\right), \cos \left(\delta_{b}\right) \sin \left(\alpha_{b}\right), \sin \left(\delta_{b}\right)\right)$ in the direction of the starting point $B^{\prime}$, and $\overrightarrow{O S}$ has coordinates

$$
\left(R_{S} \cos (\phi) \cos (\theta), R_{S} \cos (\phi) \sin (\theta), R_{S} \sin (\phi)\right),
$$

with $R_{S}=R+h$ is the geocentric radius $R$ plus the altitude $h$ of station $S, \phi$ is the geocentric latitude of $S$ and $\theta$ is the local sidereal time in $S$. An analogous expression $\overrightarrow{S F}=\overrightarrow{O S}+\lambda_{f} v_{f}$ can be obtained, where $\lambda_{f}$ is now the distance between the station $S$ and $F$, and $v_{f}$ is an unitary vector in the direction of the ending point $F^{\prime}$.

The vectorial equation

$$
\overrightarrow{B F}=\overrightarrow{S F}-\overrightarrow{S B}
$$

proposes a system of equations whose solutions $\lambda_{f}$ and $\lambda_{b}$ give an estimate of the starting and ending
TABLE 1

RESULTS OBTAINED FROM THE

OBSERVATION OF TWO STATIONS

\begin{tabular}{lrr}
\hline & Starting point & Ending point \\
\hline Longitude. & $4^{\circ} .178 \mathrm{~W}$ & $4^{\circ} .258 \mathrm{~W}$ \\
Latitude & $38^{\circ} .161 \mathrm{~N}$ & $38^{\circ} .031 \mathrm{~N}$ \\
Altitude & $106.7 \mathrm{Km}$ & $75,7 \mathrm{Km}$ \\
Distance & $189.7 \mathrm{Km}$ & $162.0 \mathrm{Km}$ \\
\hline
\end{tabular}

Time: $0.59 \mathrm{~s} \quad$ Mag.: $-4.9 \quad$ Phot. mass: $3.2 \mathrm{~g}$

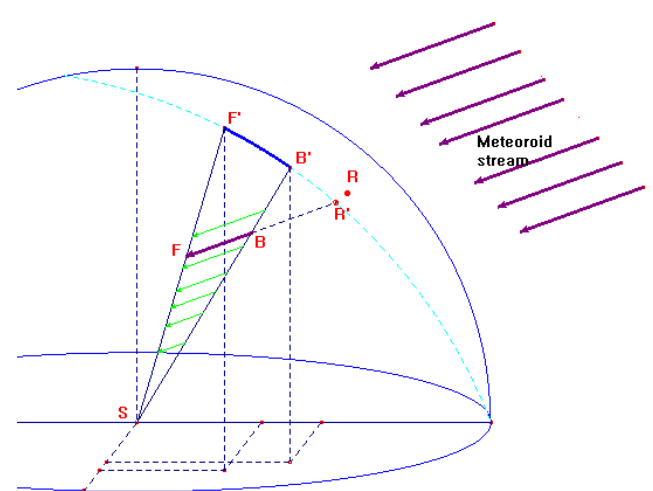

Fig. 3. In green, possible trajectories directed to $R^{\prime}$. In purple, trajectory coherent with the speed of the stream.

distances and, therefore, of the atmospheric trajectory of the meteoroid. Tables 2 and 3 have been calculated from a single image of the BOOTES-2 station using the typical speed (Madiedo 2017; Rendtel 2017 ) of the Perseids within a $\pm 3 \mathrm{~km} / \mathrm{s}$ speed interval. The concordance with the results obtained with multiple stations is remarkable. For the calculation of photometric masses, the method described in Ceplecha \& McCrosky (1976) and Madiedo (2017) has been followed.

With the previous estimate of the distances, a second check can be made between the estimated angular velocities and the typical one for shower to confirm the association of the meteoroid with the active showers.

\section{ONLY SINGLE STATION AND UNKNOWN TIME}

In this case, for each possible initial altitude $h_{i}$ there exists a unique vector $\overrightarrow{B F}$ with origin in the line $\overline{S B^{\prime}}$ at altitude $h_{i}$, end in the line $\overline{S F^{\prime}}$, whose direction is the opposite of the apparent radiant $R^{\prime}$ (see Figure 4). Using the same notation that the above section, we now propose the second degree equation in $\lambda_{b}$ :

$$
\left\|\overrightarrow{O S}+\lambda_{b} u_{b}\right\|=R+h_{i}
$$


TABLE 2

ESTIMATED ATMOSPHERIC TRAJECTORIES WITH DATA OF A SINGLE STATION FOR A RANGE OF SPEEDS (KNOWN TIME)

\begin{tabular}{lcccc}
\hline Vel. & Long. & Lat. & Alt.(Km) & Dist.(Km) \\
\hline Beginning & & & \\
\hline $56 \mathrm{Km} / \mathrm{s}$ & $4^{\circ} .179 \mathrm{~W}$ & $38^{\circ} .062 \mathrm{~N}$ & 99.6 & 176.9 \\
$59 \mathrm{Km} / \mathrm{s}$ & $4^{\circ} .186 \mathrm{~W}$ & $38^{\circ} .131 \mathrm{~N}$ & 105.1 & 186.4 \\
$62 \mathrm{Km} / \mathrm{s}$ & $4^{\circ} .193 \mathrm{~W}$ & $38^{\circ} .200 \mathrm{~N}$ & 110.5 & 195.9 \\
\hline End & & & & \\
\hline $56 \mathrm{Km} / \mathrm{s}$ & $4^{\circ} .267 \mathrm{~W}$ & $37^{\circ} .961 \mathrm{~N}$ & 73.1 & 154.1 \\
$59 \mathrm{Km} / \mathrm{s}$ & $4^{\circ} .280 \mathrm{~W}$ & $38^{\circ} .038 \mathrm{~N}$ & 77.1 & 162.3 \\
$62 \mathrm{Km} / \mathrm{s}$ & $4^{\circ} .292 \mathrm{~W}$ & $38^{\circ} .106 \mathrm{~N}$ & 81.1 & 170.5 \\
\hline
\end{tabular}

TABLE 3

MAGNITUDE AND PHOTOMETRIC MASS

ESTIMATED WITH DATA OF A SINGLE STATION FOR A RANGE OF SPEEDS (KNOWN TIME)

\begin{tabular}{ccc}
\hline Velocity & Magnitude & Phot. mass $(\mathrm{g})$ \\
\hline $56 \mathrm{Km} / \mathrm{s}$ & -5.0 & 3.9 \\
$59 \mathrm{Km} / \mathrm{s}$ & -5.1 & 4.3 \\
$62 \mathrm{Km} / \mathrm{s}$ & -5.2 & 4.8 \\
\hline
\end{tabular}

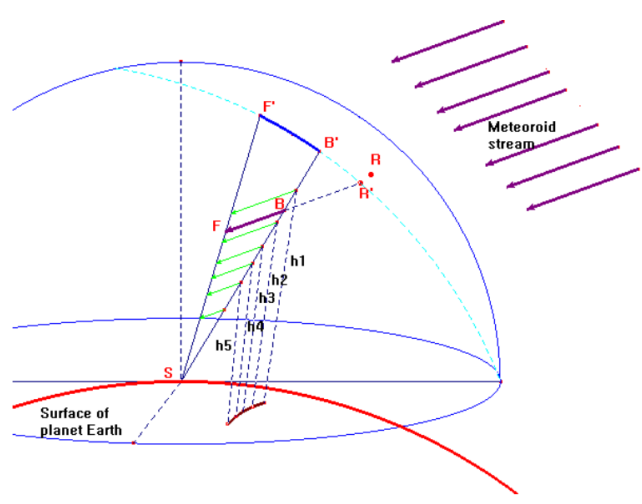

Fig. 4. Each possible trajectory (in green) starts at a different altitude. Some of then (in purple) will be within a reasonable range of altitudes.

This equation can have two solutions, one in the direction $\overrightarrow{S B}$, and another in the opposite direction. The choice is obvious. Abnormal results are indicators that the association to a shower is not correct.

Tables 4 and 5 show the results obtained for a range of initial heights between 120 and 90 kilometers.
TABLE 4

ESTIMATED ATMOSPHERIC TRAJECTORIES WITH DATA OF A SINGLE STATION FOR A RANGE OF ALTITUDES (UNKNOWN TIME)

\begin{tabular}{lccc}
\hline Alt. & Long. & Lat. & Dist. (Km) \\
\hline Beginning & & & \\
\hline $120.0 \mathrm{Km}$ & $4^{\circ} .206 \mathrm{~W}$ & $38^{\circ} .320 \mathrm{~N}$ & 212.6 \\
$112.5 \mathrm{Km}$ & $4^{\circ} .196 \mathrm{~W}$ & $38^{\circ} .226 \mathrm{~N}$ & 199.5 \\
$105.0 \mathrm{Km}$ & $4^{\circ} .186 \mathrm{~W}$ & $38^{\circ} .131 \mathrm{~N}$ & 186.5 \\
$97.5 \mathrm{Km}$ & $4^{\circ} .176 \mathrm{~W}$ & $38^{\circ} .036 \mathrm{~N}$ & 173.4 \\
$90.0 \mathrm{Km}$ & $4^{\circ} .166 \mathrm{~W}$ & $37^{\circ} .941 \mathrm{~N}$ & 160.2 \\
\hline End & & & \\
\hline $88.2 \mathrm{Km}$ & $4^{\circ} .313 \mathrm{~W}$ & $38^{\circ} .200 \mathrm{~N}$ & 185.1 \\
$82.6 \mathrm{Km}$ & $4^{\circ} .297 \mathrm{~W}$ & $38^{\circ} .112 \mathrm{~N}$ & 173.7 \\
$77.1 \mathrm{Km}$ & $4^{\circ} .280 \mathrm{~W}$ & $38^{\circ} .025 \mathrm{~N}$ & 163.4 \\
$71.6 \mathrm{Km}$ & $4^{\circ} .263 \mathrm{~W}$ & $37^{\circ} .937 \mathrm{~N}$ & 151.0 \\
$66.1 \mathrm{Km}$ & $4^{\circ} .246 \mathrm{~W}$ & $37^{\circ} .849 \mathrm{~N}$ & 139.5 \\
\hline
\end{tabular}

TABLE 5

ESTIMATED MAGNITUDE AND

PHOTOMETRIC MASS WITH DATA OF A SINGLE STATION FOR A RANGE OF ALTITUDES (UNKNOWN TIME)

\begin{tabular}{lcc}
\hline Altitude & Magnitude & Phot. mass $(\mathrm{g})$ \\
\hline $120 \mathrm{Km}$ & -5.3 & 7.7 \\
$105 \mathrm{Km}$ & -5.1 & 4.3 \\
$90 \mathrm{Km}$ & -5.0 & 3.1 \\
\hline
\end{tabular}

The above results have been calculated from a single image obtained at the BOOTES-2 station for some initial altitudes. So, even using only one station and without precise timing information, a range of magnitudes and masses can be estimated.

\section{REFERENCES}

Aznar, J. C., Castellón, A., Gálvez, F., et al. 2016, RMxAC, 48, 99

Borovička, J., Spurný, P., \& Keclíková, J. 1995, A\&AS, 112,173

Castro-Tirado, A. J., et al. 2008, SPIE, 7019

Ceplecha, Z. \& McCrosky, R. E. 1976, JGR, 81, 6257

Ceplecha, Z. 1987, BAIC2, 38, 222

Dubyago, A. D. 1961, The determination of Orbits (Santa Monica, CA: The Rand Corporation)

Madiedo, J. M. 2017, Meteoros y meteoritos, (Barcelona: Marcombo)

Rendtel, J. 2017, Meteor Shower Calendar, IMO (2017) 